\title{
Copyright and e-learning: professors' level of knowledge about the new Spanish law
}

J. Carlos Fernández-Molina, Faculty of Communication and Information

Studies, University of Granada, Granada, Spain

E. Muriel, Department of Library and Information Science, University of Granada, Granada, Spain

J. Vives-Gracia, Catalonia Government Library, Barcelona, Spain

P. Riera, CEDRO, Madrid, Spain

O. Martín, Center of Virtual Learning, University of Granada, Granada, Spain

Acknowledgements

This study was supported by the Spanish Ministry of Science and Innovation (Projects EA2008-0273 and CSO-2008-03817/SOCI).

Introduction

University distance-learning activities call for the reproduction of digital works, their physical distribution and, above all, their communication and availability to the students. The most likely event is that these works are copyrighted, so that university professors or personnel must often deal with matters regarding copyright, permission, licenses, or even possible liability due to infraction of the law or violating conditions of the licenses (Gasaway, 2001; Lipinski, 2007). It is therefore easy to understand why copyright is considered one of the main obstacles for the development of digital education (Fisher et al., 2006; Wallace, 2006).

Current technological development allows for educational material prepared by teachers to circulate outside the offices, computers or personal files of the faculty members, and be put online to be shared with other members of the educational community. It is therefore essential to be aware of the legal implications of such activities. One must be sure that the teaching resources comply with copyright legislation on the one hand, and can be protected by it on the other hand. That is, since professors can be either producers or consumers of such contents, they ought to have a clear notion of what they may do with the works of others in addition to knowing what others might do with any work they themselves have elaborated. It is nonetheless quite usual for professors to have very scanty knowledge of such matters (Smith et al., 2006); and this, as Hobbs et al. (2007) underline, can have a negative impact on the classroom creativity of professors.

Precisely because of the development of communication and information technology, copyright legislation has undergone a profound review in recent 
years, in international agreements and treaties as well as under national legislation. The European Union and Spain were by no means immune to change. In 2001, a new directive on copyright in the information society was passed (European Union, 2001), which meant to serve as a guide for the member countries so that they would modify their national copyright laws, adapting them to the digital setting, in a harmonious European way. This directive could not bypass the problem of copyright in the context of teaching. Among the exceptions of an educational nature, it includes the so-called "illustration for teaching purposes". Specifically, Article 5.3.a establishes that the Member States may include in their national laws certain limitations and exceptions to the rights of reproduction and communication to the public when used "for the sole purpose of illustration for teaching or scientific research, as long as the source, including the author's name, is indicated, unless this turns out to be impossible and to the extent justified by the non-commercial purpose to be achieved".

This directive was implemented in Spain just as it was in the rest of the European Union countries. Although it is an exception of an optional character, the Spanish copyright law of 2006 opted to include it (Spain, 2006).

Along with changes in national copyright laws, a significant impact on online teaching was dealt by the initiatives that promoted free access to information, especially licenses more flexible than the current ones. The main harvest of such attempts are the licenses encouraged by the Creative Commons Foundation (http://creativecommmons.org): the author decides which Acts he or she wishes to allow for a given work, substituting the habitual "all rights reserved" for "some rights reserved". This type of license is quite prevalent in the realm of musical and audio-visual production, and increasingly common in the world of publishing. It has also begun to extend to the world of science ("science commons") and education ("ccLearn"). The latter initiative stems from the end of 2008. Its main aim being to promote this type of license so as to freely permit modification and distribution of all types of teaching materials, to encourage standards of interoperability and tools for their reutilization, and to educate teachers and students regarding the relationship between copyright and education.

Given the novelty of Spain's legal framework and the copyleft initiatives, we consider it prime time to assess the level of knowledge of university professors about copyright problems pertaining to e-learning activities. This objective is truly relevant in the case of Spain, as the "classic" exception for educational purposes did not exist under Spanish law until the legislative reform of 2006. Implicit in the main aim of our study is a secondary but equally important objective: to determine if the professors' perception of how the current law applies coincides with its actual application.

We held that the most appropriate source of information for such research would be the actual professors teaching subjects online, in this case at the University of Granada, to whom we directed an online questionnaire survey. 
To facilitate understanding of this study and the results obtained in response to our survey, a very brief overview of Spanish copyright legislation to date is given below of the general and specific features affecting learning activities.

The fact that Spain is a country with a Continental-European law means that the distinction between economic and moral rights is essential to intellectual property laws. Hence, aside from the moral rights of paternity/attribution and integrity obligatorily acknowledged through the Berne Convention (WIPO, 1971), Spanish legislation contemplates other rights such as disclosure (the right to determine when and if a work shall be made public), withdrawal or modification. Moreover, as in all the other countries undersigning the Berne Convention, the author need not fulfil any formal requisite to secure the copyright of his work: copyright is acquired by virtue of the creative action in itself.

The main exception to copyright is that of private copying, apart from the most usual ones: quotations, news, for the benefit of libraries or similar institutions, parody, etc. However, before the 2006 reform stemming from the European Directive of 2001, Spain did not include the likewise frequent exception in favor of teaching purposes. The duration of copyright after harmonization of the protection period (European Union, 1993), transposed to Spain in 1995, went from 60 to 70 years after the author's death.

Illustration for teaching is one of the most traditional exceptions, included in most national copyright laws. It appears in the Berne Convention in Article 10.2, and permits "the utilization, to the extent justified by the purpose, of literary or artistic works by way of illustration in publications, broadcasts or sound or visual recordings for teaching, provided such utilization is compatible with fair practice" (WIPO, 1971). A noteworthy basic feature is that quantitative limitations are not established, except for the general restriction that the extent of use be "justified by purpose" and "compatible with fair practice". Use must be "by way of illustration" and "for teaching", the latter expression in particular posing quite a problem for interpretation, an issue at the core of this paper. What sort of teaching? Only face-to-face education? Only through learning institutions in the strict sense? The Committee's Report of the Stockholm Conference makes a restrictive interpretation by establishing that it applies only to those levels of teaching at all levels in educational institutions and universities, municipal and State schools, and private schools. This would leave out, for instance, adult education courses, or literacy campaigns in developing countries (Ricketson, 2003).

The European Directive regulates this copyright exception in Article 5.3a, which moreover specifies the finality of scientific research. It puts forth the right of reproduction as well as that of communication to the public, as long as the use is made in order to illustrate scientific work or teaching activities. It requires, furthermore, that use be made to that extent justified by the non-commercial purpose pursued, and that the source be indicated (except when impossible), including the author's name. Unlike other exceptions, such as that of private copying, here no system of remuneration is required. 
Implementation of this directive in 2006 thus meant its introduction for the first time in Spanish legislation, so that a second section was introduced to Article 32 , establishing that professors of formal education (programs leading to official degrees) need no authorization by the copyright holder to carry out acts of reproduction, distribution and public communication of small fragments of works, or of isolated works of a plastic nature, or figurative photography (except textbooks and university handbooks), as long as it be for the illustration of educational activities in the classroom (and to an extent justified by noncommercial purposes), that the works be already divulged, and that the name of the author and the source be included. The positive aspects of this introduction were unfortunately undermined by the final result, as Spanish lawmakers imposed multiple restrictions that do not appear in the directive (Vives-Gràcia, 2007). Why only "professors"? Why only "in the classroom"? Why only "formal education" if the directive speaks of any "educational or research purposes"? Why does it refer to "small fragments" if the directive states any works? Why does it exclude textbooks and university handbooks? Besides, the contents of the new law, as expounded, are truly confusing and contradictory. Bercovitz et al. (2006) underline the lack of clarity as to what constitutes a textbook (any book recommended by a professor?), or if it applies only to university settings. The expression "in the classroom" has particularly serious implications, apparently delimiting the classroom as a physical setting.

The latter point is especially relevant for the approach of our study. A somewhat strict interpretation of "in the classroom" leads one to infer face-to-face teaching alone, leaving out distance education. This is absurd for a law that attempts to bring legislation up to date, adapting it to the information society; yet it might seem to fit in line with the tendency of the 2006 law to further restrict that which is established in the directive. It may be no accident that the Article affirms "in the classroom" without including the expression "distance learning", as does recital 42 of the directive. Equally restrictive, limiting application to physical classrooms, is the interpretation by the Spanish State Council in its report on the draft bill, when it concludes that the expression "may be too excluding (or even unreasonable, given the unequal treatment it represents) with respect to distance learning, on line, or not face-to-face in general, types of teaching that should also be listed together with the face-to-face "in the classroom' teaching" (Consejo de Estado, 2005).

Yet, as is clearly reflected in the report by Westkamp (2007), there are great differences in the way of implementing this Article in the national laws of the Member States. Only Latvia and Spain explicitly exclude online teaching, underlining its application only to teaching "in the classroom". Though less evident, it can also be inferred from the laws of Austria, Bulgaria, Greece, Hungary, Lithuania, and Slovenia, where the context implied is that of face-toface teaching rather than online teaching (Xalabarder, 2009).

\section{Methodology}

To assess the level of knowledge on the part of professors from the University of Granada regarding copyright, in general terms as well as with specific reference to digital learning, we designed an online questionnaire that was 
made available to faculty members. The selected study population did not comprise all the university professors (over 3,500 at the UGR), but only those already participating in activities involving formal online teaching. In 2002/2003 the Centre for Online Teaching and Learning of the University of Granada began a process of digitalizing courses. The first year only seven subjects were offered online, but since then the number has increased steadily, and in $2008 / 2009$ a total of 78 subjects were taught in this way, involving 94 professors. Some professors taught more than one subject, and other subjects had more than one teacher, for which reason the numbers of professors and subjects are not equal. We consider that, for the purposes of this study, it was preferable to use a sample of professors with actual e-learning experience instead of deriving a random sample from the faculty as a whole. Moreover, during the academic year 2008/2009, the University of Granada joined the OpenCourseWare consortium initiated by MIT in 2001, so that a good part of the online subjects now offer teaching material through this open model of diffusion, and it is assumed that the participating professors are familiar with Creative Commons licenses.

The questionnaire contained 14 items, the first five about general matters of copyright, and the other nine specifically about e-learning. It featured questions with more than one valid response as well as others with only one correct answer. In May 2009 it was made available to the 94 professors through a module of surveys on the Moodle platform, and they were sent an e-mail message to explain the purpose and objectives of the survey. Full response to the questionnaire was obtained from 28 professors. One month later a new message was e-mailed out to remind them and encourage participation; this elicited six more full responses. The total number of professors correctly completing the questionnaire was finally 34 , meaning a response rate of 36.17 percent, which we consider reasonable in view of the high frequency of requests for information or participation in surveys that faculty members tend to receive by e-mail.

\section{Results and discussion}

The results are presented and commented on in the same order in which they appeared on the questionnaire, with a distinction between general and specific knowledge of the e-learning environment. Analysis of data is facilitated by the display of results in the form of tables and figures.

\section{Knowledge of a general character}

The first item on the questionnaire (responses are given in Table I) attempts to gauge the general grasp by those questioned of the classic distinction between moral rights and economic rights, particularly meaningful in a country with a Continental-European law. The results indicate that the best-known right is that of integrity ("respect of the integrity of a work and impeding any distortion, modification, mutilation or other derogatory action against it which might harm the legitimate interests or undermine its reputation"), followed by that of paternity/attribution, and somewhat thereafter, that of disclosure. It is remarkable that the most important and most easily identified moral right, 
protecting the paternity of a work, which is so apparent for example when writing a bibliography for an article or monograph, is acknowledged as a moral right by less than half (47 percent) of the participating faculty.

Since there were three valid responses in this case (disclosure, integrity, paternity), more than one option could be marked. Interestingly, only three of the 34 participants responded correctly with all three moral rights (9 percent); whereas two participants ( 6 percent) gave no correct answer at all.

The second question focused on copyright exceptions, attempting to determine how well they were known and under what conditions they apply. The results were not surprising, the best known being illustration for teaching purposes, quotations, and private copying. The first two exceptions, given by 56 percent of the professors, are directly related with their professional activity; whereas the third, private copying, is widely known because of much recent debate in Spain about the "digital canon" and the P2P networks, frequently covered by national media. Only 26 percent of participants reflected awareness of the benefits held by libraries and archives, a low percentage if we bear in mind the widespread use made of such services in the university environment. Finally, just two of the 34 professors surveyed knew of the exception in benefit of people with a disability.

As with the first item on the questionnaire, more than one option could be ticked. Yet again, responses (Table II) are disappointing in that only one faculty member demonstrated a reasonable knowledge of the content of the five limits to copyright given under the question.

Similarly disappointing are the answers to the following question about the duration of copyright, where only nine participants gave a correct response (26 percent), despite the fact that this was one of the simplest questions on the survey (Figure 1). One might surmise that many responded with the time period in vogue until 1995 (60 years), before harmonization by all the European Member States; but surprisingly, nobody gave that response. Most (24) responded 50 years, a period of protection that never governed Spanish copyright, though it was set forth for neighboring rights.

Our question about the meaning of "public domain" was answered correctly by the vast majority of the professors (76 percent); though a small percentage (18 percent) responded that works in the public domain have no moral or economic rights (Figure 2). This erroneous understanding may stem from the popular belief that one may do whatever one wishes with works of the public domain. Unlike in Anglo-Saxon countries, in civil law countries (Spain among them), the rights of paternity and integrity are perpetual. Two respondents believed that economic rights still pertained, but not the moral rights.

Another question of a very general nature was that of the need to fulfill some type of formal requirement to acquire copyright of the work created. As shown in Table III, there were just four correct responses to this item (12 percent). Given there is a broadly generalized belief that one must carry out some sort of legal procedure in order to protect a work, nearly all participants would find it 
incredible that a work has true legal protection even if it is not inscribed in a register or, at the very least, it bears the copyright symbol. Roughly a third of the participants believed that all the requisites included under the item were demanded. The fact is, since 1987, according to Spanish legislation as well as in all the countries undersigning the Berne Convention (164 at present), it is not necessary to fulfill any legal requirement in order to obtain copyright of one's own work. Article 1 of the Spanish law makes it very clear that intellectual property corresponds to the author "merely by virtue of the fact of creation".

\section{Specific knowledge in the e-learning realm}

The first item of this section presents a basic query: To whom do the teaching materials created by professors belong? (Figure 3). The valid response, "it depends on the contract or agreement between professor and university" was obtained from 15 respondents; while another gave the option that they belonged to the professor. At a glance this result strikes us as logical, but it should not be if we recall that the Centre for Online Teaching and Learning of the University of Granada signed a contract with each of the professors involved in our survey, where the ownership of rights as corresponding to one party and the other were clearly specified.

The seventh question in our survey was one of the most important, as it focused on a very fuzzy and controversial aspect of the new Spanish law: whether the illustration for teaching exception is applicable or not to e-learning. The three options presented on the questionnaire were:

1. only for face-to-face teaching;

2. only for online teaching; and

3. for both types of education.

The main response, while incorrect (as explained below) is reasonable (Table IV). If there are reasons of public interest for teaching and professors to benefit from a copyright exception, logically such a benefit is produced regardless of whether the teaching is online or not. This is the understanding reflected by 82 percent of those surveyed. As mentioned earlier, however, Spain's reformed law is absurdly restrictive in this case, establishing in its Article 32.2 that the exception is only applicable to educational learning activities taking place "in the classroom", thereby excluding e-learning.

To complement the above, the next question focused more specifically on the types of works that are covered by this copyright exception. Since textbooks and university handbooks are expressly excluded, as mentioned before, the results of Table $V$ show an anticipated high percentage of incorrect responses; and again, the persons surveyed are not to blame: It is probably logical for works benefiting from this exception to be the ones most often used in a university setting (handbooks), but precisely these, together with textbooks, are excluded. A lack of knowledge regarding this point can have important practical implications, as the professors would be the persons most likely to apply this exception to copyright; yet ironically they are largely confident in using, without permission, the types of work that are expressly not covered. 
The next two items on the questionnaire are interconnected, and have to do with the possibility of using, without permission, the complete works (or a very substantial proportion thereof) as material for e-learning courses. Most of the answers to the ninth question correctly stated that complete works or major portions thereof cannot be utilized without the permission of the copyright holder (82 percent), whereas just 9 percent believed that they could indeed be used. Notwithstanding, when we moved on to the tenth item, the variant matter of whether those works accessible on the internet could be used, quite different results were obtained. The previous 9 percent that thought complete works could be used without permission now increased considerably, to 35 percent. Also noteworthy is a 6 percent increase in the option "don't know", indicating the added difficulty of this topic when involving works placed on the internet. These findings seem to obey an extended belief that everything available on the internet belongs to the "public domain", and can therefore be used without any control or standard. A comparison of results is shown in Figures 4 and 5.

The vast growth of electronic resources available in any university library has led to the generalized use by faculty members of databases (the first source to be included in digital library collections), or the more recent electronic journals and e-books. These resources, unlike analogical works, are not owned by the library, but merely used under licensed terms. We wished to know how aware professors are about changes in the conditions for use of such works, and asked if they could be used with absolute freedom, or with some type of restriction. Although most responses to question 11 were correct (68 percent), replying that restrictions do indeed apply, we also found considerable misunderstandings as to what can be done with the materials accessed through the library. Nearly a third of the faculty members were poorly informed, with 20 percent giving an incorrect response, and an additional 12 percent answering that they did not know.

A key question that could not be overlooked was that of the legality/illegality of internet links, a heatedly debated topic on the digital scene. Regarding this matter, several contradictory sentences have been delivered in different countries. However, experts seem to have arrived at a certain consensus with respect to the fact that a normal link - not the "deep" or "embedded" links involves no infraction of copyright whatsoever (reproduction, distribution, communication to the public, transformation), and the material thus accessed may be assimilated into quotation. This perception appears to be very common, with 91 percent of the professors surveyed responding that a link from their online subjects to the works of other authors does not constitute an illicit act. No participant answered that it was illegal, as the remaining 9 percent responded "don't know".

In view of the development and success of copyleft-type licenses, especially those of Creative Commons, and their appropriateness for use in the realm of learning, we asked some basic questions about them. The thirteenth item on our questionnaire attempted to assess the level of knowledge about copyleft licenses; question 14, of a complementary nature, inquired whether the professors knew how to make use of its widespread availability on the web or not. As Figure 6 shows, only 21 percent responded correctly to the first of these 
questions, revealing a generalized lack of knowledge about the nature of copyleft terms. Apparently, the prevailing notion is that this type of license stands as a renouncement of the economic part of copyright, meaning that the creator keeps only the moral rights (according to 68 percent of the responses). However, it is quite common for the authors using copyleft licenses to decide that they do not allow derivative works. That is, they maintain one of their economic rights, the right of transformation.

In consonance with the above question, the results of the complementary query as to where or how to find contents with a copyleft-type license, a scarce 35 percent of the surveyed faculty members knew how to locate them. One solid a priori reason had led us to surmise that the level of knowledge would have been greater than the meagre awareness actually reflected by our data: the fact that so recently (2008/2009) the Centre for Online Teaching and Learning of the University of Granada had joined the OpenCourseWare Consortium, which uses Creative Commons licenses.

\section{Conclusion}

E-learning programs are complex and costly to implement, which suggests that they are a valuable asset for universities, and therefore should be adequately managed and protected. Our findings, however, from a survey directed precisely to those professors who would supposedly have better information in this regard, underline a vast lack of knowledge about copyright, both in general aspects and in matters specific to digital learning. To remedy these deficiencies in faculty preparation, there should be a process of information literacy, directed at university professors and centering on legal issues related with the property, access to and use of digital information. The university library could play a key role in this formative process, given its privileged position among faculty members and information resources.

It is likewise desirable that universities themselves take on a more active role in such matters. For instance, we might follow the US "TEACH Act" model, whose section 110(2)(D)(i) calls for each institution to establish guidelines or policies about copyright, and to provide information related therewith to professors, students and relevant staff members (United States, 2001).

As for Spanish legislation in particular, the results presented here clearly reveal that further reform of the law is indispensable to arrive at a new law that does not create so many obstacles for the development of online educational activities. The responses to items seven and eight of our survey demonstrate a strong discrepancy between the text of the law and the notion that the professors hold regarding what legislation should ideally establish. It is unfortunate that the introduction of the "illustration for teaching" exception in the new Article 32.2 of the Spanish law has been so deficient, reducing to practically bare bones the possibilities left open by the European directive. The exclusion of scientific research, of non-formal education (so important nowadays) and, above all of the educational activities developed outside "the classroom" - that is, online teaching - is absolutely unjustifiable. Once again, the reforms of the laws that (in theory) are meant to adapt them to the new 
technological context prove frustrating and of scarce usefulness, as they are impregnated with a strong "pre-digital" philosophy. In short, the legislative reform is blind to technological and educational reality.

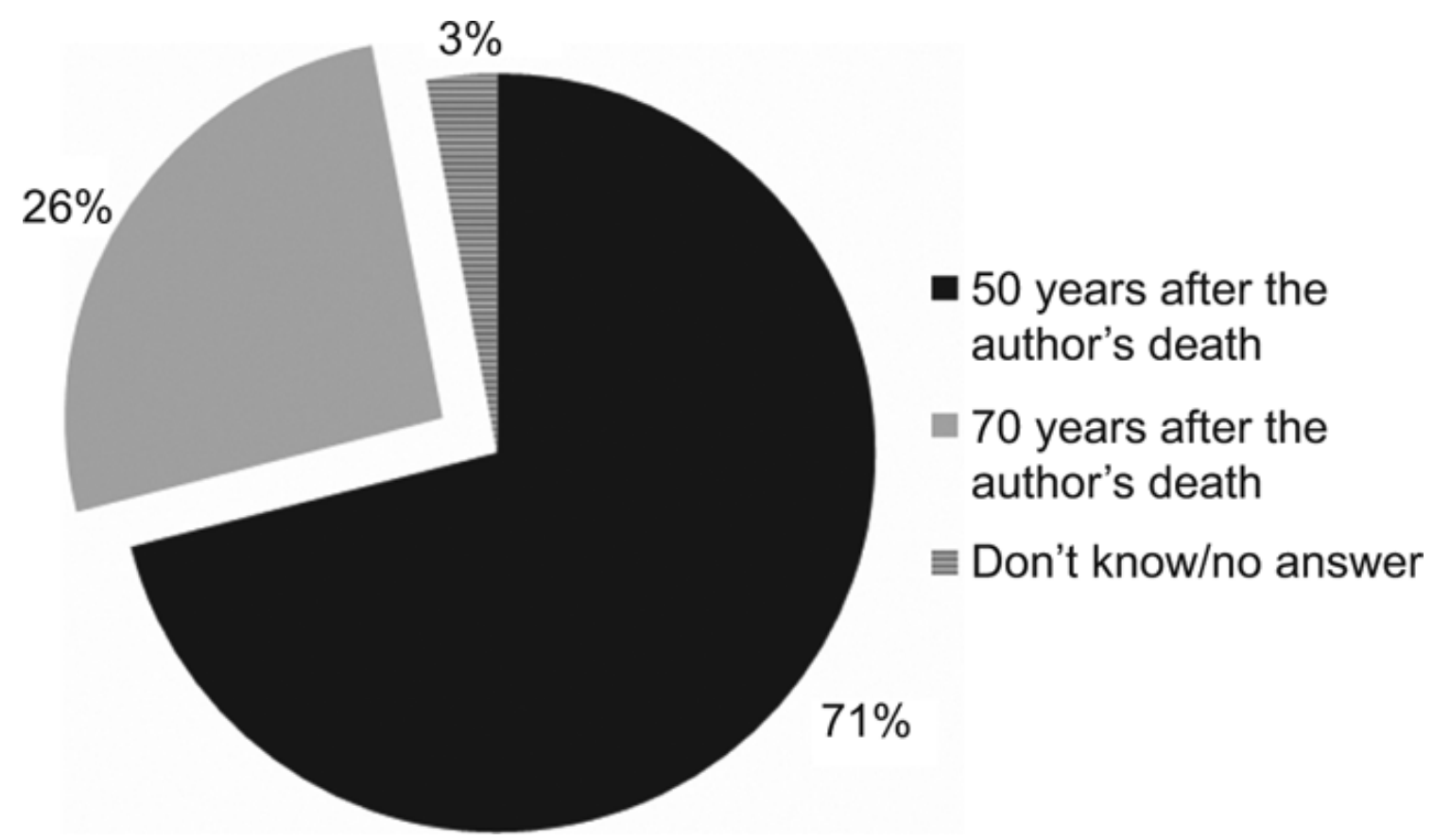

Figure 1Duration of copyright

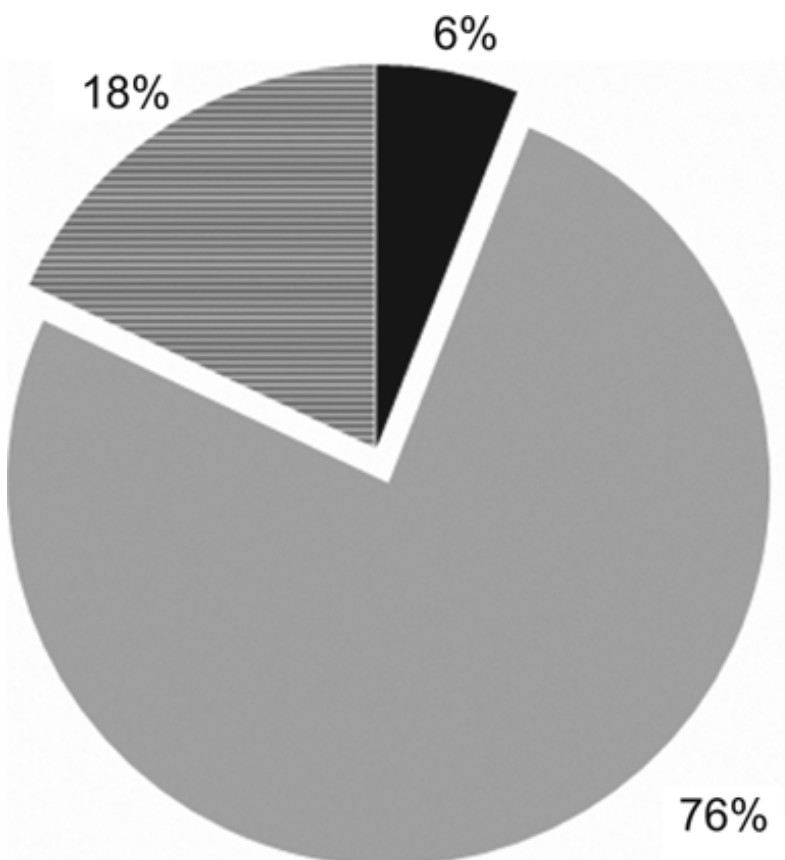

- The author has no moral rights, only economic rights

- The author has no economic rights, but maintains some moral rights

트 The author has no moral or economic rights

Figure 2What does "public domain" mean? 


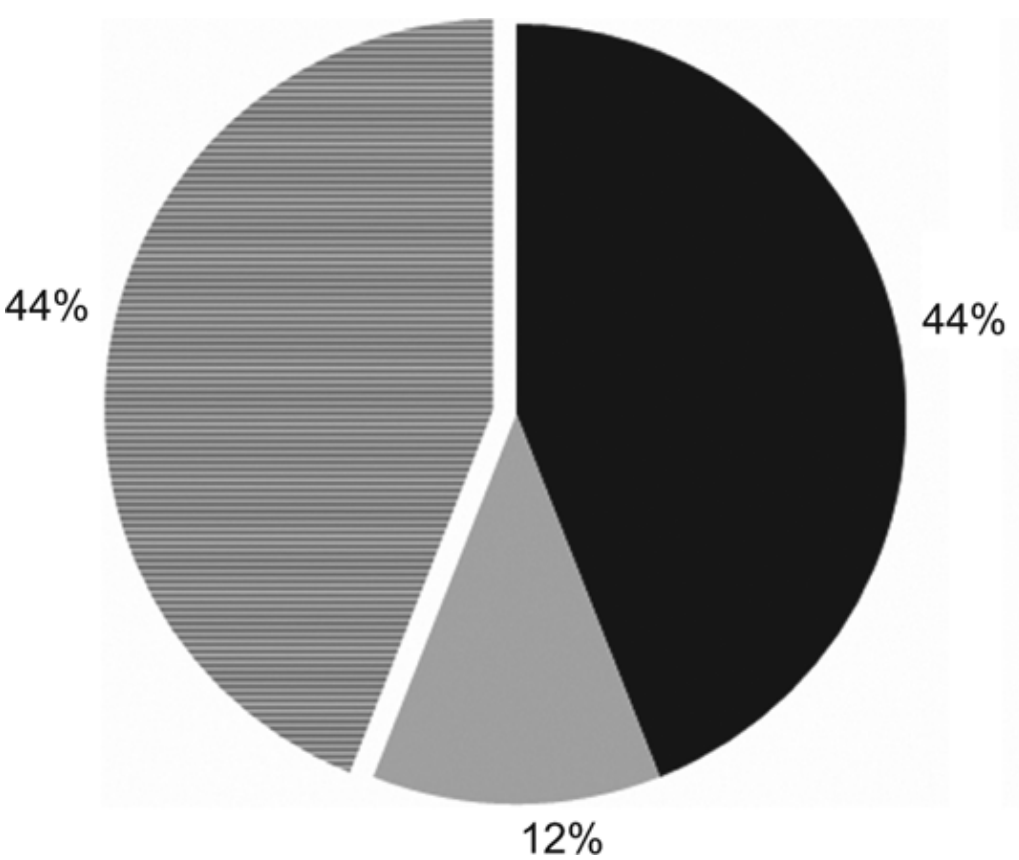

- They belong to the professor

- They belong to the university

트 It depends on the contract or agreement between professor and university

Figure 3Ownership of the teaching materials



- Yes

No

豆 Don't Know

Figure 4Incorporation of complete works or large portions 


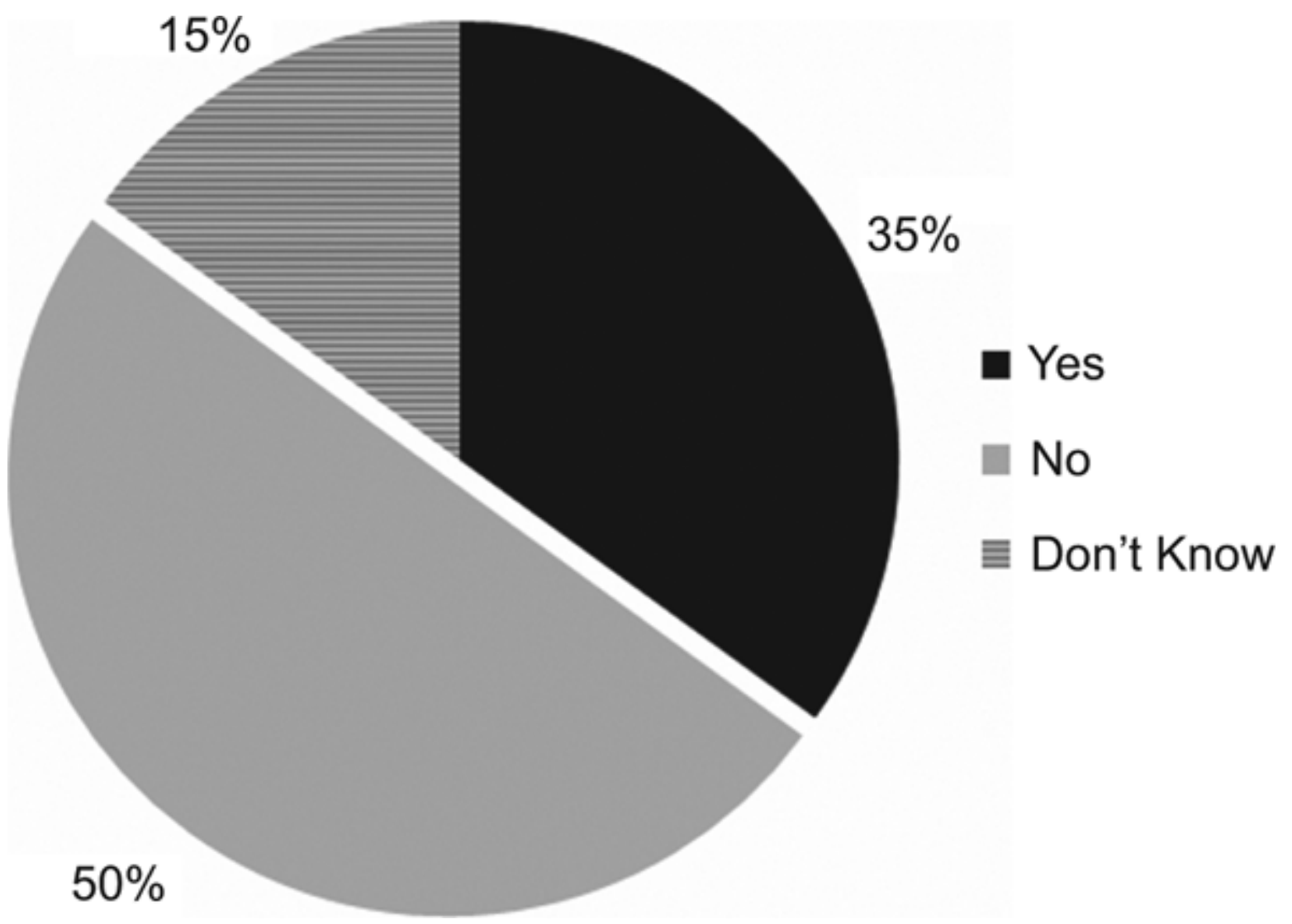

Figure 5Incorporation of complete works or large portions (on the internet)
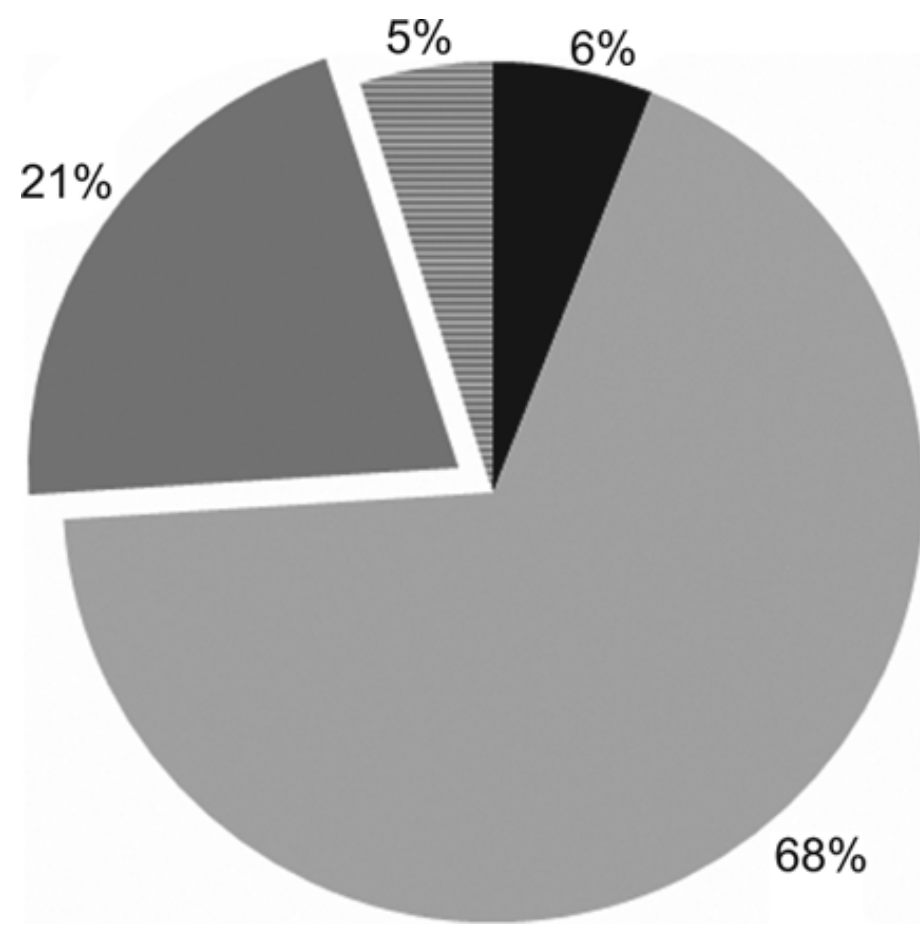

Figure 6What are copyleft licenses?
- The author renounces all his/her rights

The author renounces all economic rights, but not the moral rights

The author decides which rights are renounced and which are maintained

트 Don't know/no answer 


\begin{tabular}{|c|c|c|c|}
\hline Right & Frequency & Percentage & \\
\hline Communication to the public & 7 & 21 & Copyright can be broken \\
\hline Distribution & 0 & 0 & down into moral rights \\
\hline Disclosure & 9 & 26 & and economic rights. \\
\hline Integrity & 23 & 68 & Indicate which of the \\
\hline Paternity/attribution & 16 & 47 & following constitute \\
\hline Reproduction & 2 & 6 & moral rights \\
\hline
\end{tabular}

Table ICopyright can be broken down into moral rights and economic rights. Indicate which of the following constitute moral rights

\begin{tabular}{|c|c|c|c|}
\hline Exception & Frequency & Percentage & Table II. \\
\hline Private copying & 18 & 53 & certain \\
\hline For the benefit of people with a disability & 2 & 6 & Indicate which ones you \\
\hline Quotations & 19 & 56 & are aware of (knowing \\
\hline Illustration for teaching & 19 & 56 & their content and \\
\hline For the benefit of libraries and archives & 9 & 26 & conditions) \\
\hline
\end{tabular}

Table IICopyright is subjected to certain exceptions. Indicate which ones you are aware of (knowing their content and conditions)

\begin{tabular}{|c|c|c|c|}
\hline Prerequisite & Frequency & Percentage & Toblo III \\
\hline Inscription in the register of intellectual property & 16 & 47 & What formal \\
\hline Inclusion of the copyright symbol & 2 & 6 & requirements must be \\
\hline Making legal deposit & 2 & 6 & met to acquire copyright \\
\hline All three of the above & 10 & 29 & of the work we have \\
\hline No formal prerequisite is necessary & 4 & 12 & created? \\
\hline
\end{tabular}

Table IIIWhat formal requirements must be met to acquire copyright of the work we have created?

Table IV.

Under Spanish law there

is a copyright exception

for teaching purposes. It

is applicable to:

\begin{tabular}{lll}
\hline Type of teaching & Frequency & Percentage \\
\hline Face-to-face teaching & 5 & 15 \\
Online teaching & 1 & 3 \\
Both & 28 & 82
\end{tabular}

Table IVUnder Spanish law there is a copyright exception for teaching purposes. It is applicable to:

Table V.

This exception favoring teaching does not apply to all types of work.

\begin{tabular}{lcc}
\hline Type of work & Frequency & Percentage \\
\hline Journal article & 11 & 32 \\
Photograph & 7 & 21 \\
Textbook & 21 & 62 \\
Handbook & 21 & 62 \\
Monograph & 15 & 44
\end{tabular}

Table VThis exception favoring teaching does not apply to all types of work. Indicate to which one(s) it does apply 
References

Bercovitz, R., Garrote, I., González, A., Sánchez, R. (2006), Las reformas de la Ley de Propiedad Intelectual, Tirant Lo Blanch, Valencia, .

Consejo de Estado (2005), "Dictamen del Anteproyecto de Ley por la que se modifica el texto refundido de la Ley de Propiedad Intelectual, aprobado por Real Decreto Legislativo 1/1996 de 12 de abril (referencia 187/2005)", available at:

www.boe.es/aeboe/consultas/bases_datos_ce/doc.php?coleccion=ce\&id=2005187 (accessed 19 March 2010), .

European Union (1993), Council Directive 93/98/EEC of 29 October 1993

Harmonizing the Term of Protection of Copyright and Certain Related Rights,

Official Journal L 290, 24 November, .

European Union (2001), Directive 2001/29/EC of the European Parliament and of the Council of 22 May 2001 on the Harmonisation of Certain Aspects of Copyright and Related Rights in the Information Society, Official Journal L 167, 22 June, .

Fisher, W., Palfrey, J., McGeveran, W., Harlo, J., Gasser, U., Jaszi, P.W. (2006), The Digital Learning Challenge: Obstacles to Educational Uses of Copyrighted Material in the Digital Age, a foundational white paper, Berkman Center Research Publication No. 2006-09, available at:

http://ssrn.com/abstract=923465 (accessed 19 March 2010), .

Gasaway, L.N. (2001), "Impasse: distance learning and copyright", Ohio State Law Journal, available at:

http://moritzlaw.osu.edu/lawjournal/issues/volume62/number2/gasaway.pdf (accessed 19 March 2010), Vol. 62 No.2, pp.783-820.

Hobbs, R., Jaszi, P., Haufderheide, P. (2007), "The cost of copyright confusion for media literacy", The Center for Social Media, Washington, DC, available at: www.centerforsocialmedia.org/files/pdf/Final_CSM_copyright_report.pdf (accessed 19 March 2010), .

Lipinski, T.A. (2007), "Legal issues in the development and use of copyrighted material", in Moore, M.G. (Eds), Handbook of Distance Education, Lawrence Erlbaum, Mahwah, NJ, pp.451-69.

Ricketson, S. (2003), "WIPO study on limitations and exception of copyright and related rights in the digital environment", available at:

www.wipo.int/edocs/mdocs/copyright/en/sccr_9/sccr_9_7.pdf (accessed 19 March 2010), .

Smith, K.H., Tobia, R.C., Plutchak, T.S., Howell, L.M., Pfeiffer, S.J., Fitts, M.S. (2006), "Copyright knowledge of faculty at two academic health science campuses: results of a survey", Serials Review, Vol. 32 No.2, pp.59-67. 
Spain (2006), Ley 23/2006, de 7 de Julio, por la que se modifica el texto refundido de la Ley de Propiedad Intelectual, aprobado por el Real Decreto Legislativo 1/1996, de 12 de abril, .

United States (2001), Technology, Education, and Copyright Harmonization Act of 2001, available at: http://frwebgate.access.gpo.gov/cgibin/getdoc.cgi?dbname=107_cong_bills\&docid=f:s487es.txt.pdf (accessed 19 March 2010), .

Vives-Gràcia, J. (2007), "Confidencialidad y derechos de autor en un proyecto de intranet", El Profesional de la Información, Vol. 16 No.3, pp.188-205.

Wallace, M. (2006), "An investigation into copyright concerns as a barrier to the widespread development of e-learning practice within Scottish further education colleges", Information \& Communication Technology Law, Vol. 15 No.1, pp.79119.

Westkamp, G. (2007), Study on the Implementation and Effect in Member States' Laws of Directive 2001/29/EC on the Harmonisation of Certain Aspects of Copyright and Related Rights in the Information Society. Part II Implementation of Directive 2001/29/EC in the Member States, Queen Mary University, London, available at:

www.ivir.nl/publications/guibault//nfoSoc_Study_2007.pdf (accessed 19 March 2010),

WIPO (1971), Berne Convention for the Protection of Literary and Artistic Works, Paris Act of July 24, 1971, as amended on September 28, 1979, available at: www.wipo.int/treaties/en/ip/berne/trtdocs_wo001.html (accessed 19 March 2010), .

Xalabarder, R. (2009), Study on Copyright Limitations and Exceptions for Educational Activities in North America, Europe, Caucasus, Central Asia and Israel, available at:

www.wipo.int/edocs/mdocs/copyright/en/sccr_19/sccr_19_8.pdf (accessed 19 March 2010), . 